\title{
TTR
}

Traduction, terminologie, re?daction

\section{Maria Tymoczko and Edwin Gentzler (eds.). Translation and Power. University of Massachusetts Press, 2002, 244 p.}

\section{Andrew Clifford}

Volume 17, numéro 2, 2e semestre 2004

Traduction, éthique et société

Translation, Ethics and Society

URI : https://id.erudit.org/iderudit/013279ar

DOI : https://doi.org/10.7202/013279ar

Aller au sommaire du numéro

\section{Éditeur(s)}

Association canadienne de traductologie

ISSN

0835-8443 (imprimé)

1708-2188 (numérique)

Découvrir la revue

Citer ce compte rendu

Clifford, A. (2004). Compte rendu de [Maria Tymoczko and Edwin Gentzler (eds.). Translation and Power. University of Massachusetts Press, 2002, 244 p.] TTR, 17(2), 191-192. https://doi.org/10.7202/013279ar d'utilisation que vous pouvez consulter en ligne.

https://apropos.erudit.org/fr/usagers/politique-dutilisation/ 


\section{Maria Tymoczko and Edwin Gentzler (eds.). Translation and Power. University of Massachusetts Press, 2002, 244 p.}

In the post-war period, attention in Translation Studies has been directed at ever-widening spheres, focusing at first on linguistic structures, later on textual forms and discursive functions, and more recently on the human actors that use them. This book is consistent with the third trend, and each of the 12 essays it contains invites the reader to consider translation not as an objective exercise between a source and a target language, but rather as the point of contact between peoples who do not always share the same access to power.

Overall, the book impresses through its variety. The contributors address a range of interesting topics, including literary translation, community interpreting, legal translation, and film dubbing. In addition, the topics are analyzed with tools from a number of disciplines such as history, philosophy, political science, and postcolonial studies. Within this short collection, it is likely that at least one essay will capture the attention of most readers who are interested in translation and interpreting. Yet at the same time, the various contributions fit together in a coherent manner, because of two themes that are woven throughout the book.

First, a number of essays underscore the notion that, because it is a human activity, translation necessarily involves power. And in making this case, the contributors point out the times and places where translation and power have begun to be examined and where further research is warranted. For example, Michael Cronin recommends that Interpreting Studies take a "cultural turn" and move away from the "paradigm" of depoliticized and minimally contextualized experiments on conference interpreting and towards an examination of variables such as social class, education, gender and age in the often-neglected realm of community interpreting.

Second, the conception of power presented in the book's pages helps the reader move beyond a dualistic representation of "powerful" versus "powerless", and towards a more complex understanding. The translator is frequently discussed not as a compromised figure with conflicting allegiances to the source- and target collectivities, but rather as someone whose double role allows for an exploration of hybridization, blurring positions, and shifting power dynamics. In Sherry Simon's discussion of Gayatri Spivak and her 
English translation of Bengali writer Mahasweta Devi, it is noted that Spivak's work intentionally targets both Anglo-American audiences and English-language Indian readers. Moreover, it does so in a manner that refuses to present Devi as an exotic and reified artifact, because this would blind Western readers to the multiple differences that make up the realities of the Third World.

Yet the book also has its shortcomings. Chief among these is the fact that many authors seem to have interpreted the title quite literally, discussing "translation" on one hand, and "power" on the other, but offering few pragmatic suggestions about how connections between the two are to be made. The book is conceptual, but provides few examples of what those concepts mean in practical terms, and as Henri Meschonnic once observed, “[t]oute théorie tient, plus qu'elle ne croit tenir, à ses exemples.” (Pour la poétique II, 1973, Paris, Gallimard, p. 335). As a result, the reader is left with a number of questions. How might we examine actual translations to see traces of power structures? In which specific instances have translations been used to support or subvert uses of power? For instance, it would have been instructive for the reader if Simon had presented passages from Spivak's translation that showed how her work simultaneously addressed Anglo-American and Indian readers, and how she avoided homogenizing an exotic product for a naïve Western audience. Similarly, Cronin could have made his point more clearly by painting for scholars in Interpreting Studies a picture of what research might look like after his "cultural turn". His discussion of colonial history and travel writing is interesting, but what is missing is the link to show us how these topics might inform an actual study of power dynamics in community interpreting today.

Yet perhaps it is the case that the contributors to this volume have so successfully launched discussion on a fascinating topic that the reader unfairly demands more, more, more. To see the book's shortcomings addressed, it may be that all we need do is wait a short span for not-so-distant research to take a more empirical, illustrative approach. Until that time, this volume makes an admirable foray into what is unquestionably an important domain.

\section{Andrew Clifford University of Toronto}

